\title{
Does Inflation Targeting Matter? A Reassessment
}

\author{
by \\ Luke B. Willard \\ Princeton University \\ CEPS Working Paper No. 120 \\ February 2006
}

The author would like to thank Julio Cacho-Diaz, Ashley Miller, Glenn Otto, participants at the London Business School's Trans-Atlantic Doctoral Conference and especially Alan Blinder for comments. He would also like to thank Thomas Wu for his data and the Center for Economic Policy Studies, Princeton University for financial support. All errors are the author's. 


\title{
Does Inflation Targeting Matter? A Reassessment \\ Luke Willard, Economics Department, Princeton University*,**
}

\begin{abstract}
This paper uses a number of identification approaches (using instrumental variables, assumptions about heteroscedasticity and panel fixed effects) to estimate the effect of inflation targeting on inflation. Generally, it finds the effect is small and insignificant.
\end{abstract}

JEL Classification Numbers: E31, E52

Keywords: Inflation; Monetary policy

*The author would like to thank Julio Cacho-Diaz, Ashley Miller, Glenn Otto, participants at the London Business School's Trans-Atlantic Doctoral Conference and especially Alan Blinder for comments. He would also like to thank Thomas $\mathrm{Wu}$ for his data and the Center for Economic Policy Studies, Princeton University for financial support. All errors are the author's.

**The author can be contacted at Luke Willard, Economics Department, Princeton University, Princeton NJ 08544, USA Tel: 1609258 2165, Fax:1 609258 6419, Email: lwillard@princeton.edu 


\section{Introduction}

A number of countries have adopted inflation targeting and a substantial literature exists on the virtues of inflation targeting in reducing inflation (e.g. Bernanke et al., 1999).

However, the reported results conflict. This paper will attempt to reconcile the discrepancies and shed more light on the effect of inflation targeting on inflation using a number of identification approaches.

The seminal paper in the previous literature is Ball and Sheridan (2003). They compare the inflation performance of inflation targeters to those of non-targeters and find that while inflation targeters reduced their inflation rates after inflation targeting, this effect goes away once one controls for past poor performance. They suggest that this is due to regression to the mean. However subsequent work, grappling with the potential problems of cross-sectional analysis, has cast doubt on their results. Wu (2004a), using fixed time and country effects, finds that OECD countries that were inflation targeters had lower inflation rates even controlling for past inflation. In a revised version of Wu's paper (2004b), he recognizes the problems of using differences in differences estimators. He argues that a valid approach to deal with this problem is to use Arellano-Bond panel estimation (1991) as long as the errors are not serially correlated. He finds no evidence of serial correlation and hence argues that his estimates, which suggest inflation targeting significantly reduces inflation, are reliable. ${ }^{1}$

1 Others have also examined this issue. For example Levin et al (2004), IMF (2005), Petursson (2004) and Truman (2003) look at the effect of inflation targeting on samples that include developing countries. Vega and Winkelried (2005) present results for both developing and developed countries using matching methods which suggests that inflation targeting has a significant effect on inflation. Differences between 
Hyvonen (2004) confirms Ball and Sheridan's result that lagged inflation is important for explaining recent inflation performance of OECD countries. However Hyvonen finds that lagged inflation does not help predict inflation in the 1970s. Hyvonen also finds reversion to the mean in inflation when developing countries are included in the sample for the 1990s. Hyvonen interprets these results as being consistent with a global policy of inflation targeting in the 1990s whether or not countries formally adopted inflation targets. This suggests that perhaps any regime which is focused on keeping inflation low may be effective in achieving this goal.

This present paper seeks to reassess whether inflation targeting reduces inflation. Given the conflicting evidence, we seek to understand better the results of $\mathrm{Wu}$ and Ball and Sheridan. In addition to reconciling these two sets of results, we use instrumental variables and other identification approaches to provide more evidence about the likely effect of inflation targeting on inflation. We do not claim to be able to identify the effect of any global effort to reduce inflation in the 1990s. To preview the results, we find that there is little evidence that inflation targeting has an economically or statistically significant effect on inflation using a number of estimation approaches. This conclusion is compelling as (a) we use a dataset which had previously been used to argue that inflation targeting was significant and (b) we confirm a number of existing results in the literature.

their results and those presented here are likely due to the different identification approaches employed. For example, our preferred panel results rely on more lags (a larger information set). Also the nature of the identification assumptions are different (see for example Heckman and Navarro-Lozano (2004) for relevant discussion). 


\section{Method}

One issue is how to reconcile Wu's and Ball and Sheridan's results. Wu's (2004a) results use panel data with country and time fixed effects with a dummy variable, indicating whether the country is currently an inflation targeter. Ball and Sheridan run crosscountry regressions examining what factors affected how inflation changed from roughly 1960-85 to the 1990s (when inflation targeting was practiced). The regressions Ball and Sheridan ran are essentially of the form:

$$
\Delta \pi_{i}=\alpha+\beta T_{i}+\psi \pi^{*}{ }_{i}+\varepsilon_{i}
$$

where change in pi is the difference in inflation between the current and past (when no countries practiced inflation targeting) periods, $\mathrm{pi}^{*}$ is the pre-inflation target inflation rate and $\mathrm{T}$ is the indicator for being an inflation targeter. $\mathrm{i}$ is the country index. Wu's regressions are variants of

$$
\Delta \pi_{i t}=\alpha_{i}+\delta_{t}+\beta T_{i t}+\psi \pi_{i t-1}+\varepsilon_{i t}
$$

where $i$ is the country index and $t$ indicates the time period where he uses quarterly data.

Prima facie, the panel estimates use more observations than the cross-sectional estimates, so we are more likely to get more precise estimates from the panel. However, Bertrand, Duflo and Mullianathan (2002) discuss how the panel approach, when there is serial dependence in both the dependent variable and in the treatment variable (i.e. the indicator that the country is an inflation targeter), will lead to misleading standard errors. As there is persistence through time in both inflation and the inflation targeting dummy, this seems 
like a potential concern here. So we use a number of approaches that are immune to this problem to assess which result appears more reliable.

Using Wu's data, we run a specification similar to that of Ball and Sheridan which compares average inflation before and after the inflation targeting period. Though the ordinary least squares standard errors are correct, the estimates may be less precise as we are reducing the number of data points by aggregating data.

We rerun the regressions similar to $\mathrm{Wu}(2004 \mathrm{~b})$ using the Arellano-Bond estimation technique. Finally, we rerun the regressions of $\mathrm{Wu}$ (2004a) except we calculate the standard errors using the "placebo" approach discussed in Bertrand et al. Specifically this involves running many regressions replacing the actual treatment variable with a generated variable where we randomly choose when countries became inflation targeters. (In effect we are making some assumptions about the statistical properties of the inflation targeting variable such as once a country becomes an inflation targeter it continues to be one.) As we randomly choose the timing of this transition rather than use the actual data, this variable should be insignificant. So, by replicating these regressions many times, we get a distribution of coefficient values under the null that inflation targeting is insignificant. Using this distribution, we can determine whether the observed coefficient value is statistically insignificant. In essence, we are going to show that we can replicate Ball and Sheridan's results using Wu's data. We are also going to show that when using the placebo laws or the Arellano Bond estimation technique, the inflation targeting 
variable is insignificant. These two results suggest that Ball and Sheridan's results and conclusions are supported by Wu's data.

Another issue is that Ball and Sheridan's ordinary least squares results do not necessarily imply that inflation targeting was irrelevant for the lowering of inflation in inflation targeting countries, because of potential endogeneity (as Gertler, 2003, discusses). For example countries with histories of high inflation or expecting future high inflation are more likely to have felt compelled to adopt inflation targets. There are a number of ways to account for endogeneity. The first and more obvious approach is to use an instrument for being an inflation targeter. We will use as instruments (a) being an English speaking country and (b) the interaction between this and having high inflation. This identification approach assumes that sharing a common language means that the central bank and government were more likely to be influenced by the same theories about how to effectively fight inflation. We will also use as an instrument Cukierman et al's (1992) measure of central bank independence in 1980-89 as central banks that had less historical independence may have greater need to become inflation targeters to indicate that they would be vigilant in fighting inflation. Consistent with this, Boschen and Weise (2004) provides some evidence that independence effects inflation performance. As a third instrument, we will use information about benefit entitlements during the 1980s. Di Tella and MacCulloch (2001) argue and provide some empirical evidence that higher unemployment benefits may mean the central bank is less concerned about the costs of unemployment and hence focuses more on reducing inflation. By this reasoning, economies which have had histories of low unemployment benefits and/or high inflation 
are more likely to be perceived to lack a credible commitment to low inflation and hence are more likely to adopt inflation targeting to try to gain credibility.

One potential concern is the validity of these instruments. It is not clear how language should directly affect the inflation process. Also the effect of past central bank institutions and credibility on current inflation seems most likely to be through current institutions (like whether the central bank is an inflation targeter). Hence it seems reasonable to believe that the language and Cukierman credibility measure are valid instruments. A more plausible concern is that unemployment benefits in the 1980s may not be a valid instrument. Specifically, 1980s unemployment benefits may affect central bank behavior in the 1990s, through mechanisms other than their role in whether the central bank became an inflation targeter. For example, as unemployment benefits are relatively persistent, 1980s benefits could also influence central bank behavior through their correlation with benefits in the 1990s.

We also employ another identification approach which does not rely on an instrument. It assumes that the structural model can be represented as follows:

$$
\begin{aligned}
& \Delta \pi_{i}=\alpha+\beta T_{i}+\psi \pi^{*}{ }_{i}+\varepsilon_{i} \\
& T_{i}=\delta+\rho \pi^{*}{ }_{i}+u_{i}
\end{aligned}
$$

So the first equation describes inflation determination and the second equation is a selection equation for being an inflation targeter. With these assumptions, we can estimate the following two equations by least squares consistently ${ }^{2}$ :

$2 \mathrm{We}$ can consistently estimate the second equation if $\mathrm{E}\left(\mathrm{u} \mid 1, \pi^{*}\right)=0$ which is satisfied if 


$$
\begin{aligned}
& \pi_{i}=(\alpha+\beta \delta)+(1+\beta \rho+\psi) \pi_{i}{ }_{i}+\left(\beta u_{i}+\varepsilon_{i}\right) \\
& T_{i}=\delta+\rho \pi_{i}+u_{i}
\end{aligned}
$$

The covariance matrix for the reduced form errors are:

$$
\left(\begin{array}{cc}
\beta^{2} \sigma_{u}^{2}+\sigma_{\varepsilon}^{2}+\beta \sigma_{u \varepsilon} & \beta \sigma_{u}^{2}+\sigma_{u \varepsilon} \\
\beta \sigma_{u}^{2}+\sigma_{u \varepsilon} & \sigma_{u}^{2}
\end{array}\right)
$$

Based on the assumptions made so far, we cannot identify the parameter of interest, beta. However, we can identify beta by making any one of a number of assumptions. One is to assume that the structural error on the first equation in the system described by (2) varies depending on whether the country was a high or low inflation country in the past. ${ }^{3}$ This is consistent with the idea, argued elsewhere, that inflation uncertainty increases with the level of inflation. ${ }^{4}$ A natural way of capturing this is to assume that countries that had higher than average inflation in the past have a structural error for inflation which is $\mathrm{A}>1$ times the size of the structural error of low inflation countries (so the variance is A squared times bigger and the covariance with the other structural error is A times bigger). This will result in the covariance of the reduced form errors differing between the high and the low inflation countries. An alternative view might be that central banks with histories of past high inflation may be more vigilant at mitigating the effect of inflation

$0=\mathrm{P}\left(\mathrm{T}=1 \mid \pi^{*}\right)\left(1-\delta-\rho \pi^{*}\right)+\mathrm{P}\left(\mathrm{T}=0 \mid \pi^{*}\right)\left(-\delta-\rho \pi^{*}\right)$. A necessary condition for this to be true is that $\left(1-\delta-\rho \pi^{*}\right)$ and $\left(-\delta-\rho \pi^{*}\right)$ are of opposite signs which given our estimates of the parameters (see below) is true for every observation of our data.

3 This is an application of Rigobon's (2003) approach of using heteroscedasticity to identify the parameter of interest.

4 Andersen and Gruen (1995) observe that average inflation is correlated with inflation variability. 
shocks in the future and hence that A may be less than one. Either way, as long as A does not equal one, we can estimate beta and the other parameters using $\mathrm{GMM}^{5}$

\section{Results}

To reconcile the $\mathrm{Wu}$ and Ball and Sheridan results, first we used Wu's data to estimate models very similar to Ball and Sheridan's. Specifically we estimate cross-sectional models where inflation is average quarterly inflation from 1995 and past inflation is average quarterly inflation from 1985 to $1989 .{ }^{6}$ This essentially captures the periods before treatment (no country was an inflation targeter before 1990) and after treatment. ${ }^{7}$ We include past inflation as a control as this could effect both current inflation and the decision to become a targeter. As a simple check for whether the results appear sensitive to potential endogeneity bias, we perform instrumental variables regressions. ${ }^{8}$ As another check for robustness, we also examine whether the results were sensitive to stopping the

5 The assumption that parameters like beta and psi are the same for the high and low inflation countries could be concerning. However as this assumption is standard in the literature, it seems like a natural assumption to make in any attempt to reconcile apparently conflicting results in that literature.

6 For more details about the data, refer to the Appendix.

7 Except for the following cases, all inflation targeters in the sample were consistently targeting after 1995. Switzerland became an inflation targeter in 2000 and for the purposes of the cross-sectional analysis is considered a non-targeter. Spain and Finland were targeters until 1999 when they adopted the EMU. They are treated as inflation targeters for the cross-sectional analysis.

8 We include both the English speaking and the Cukierman variables as variables in column (4) of Table 1 as the Cukierman variable is a weak instrument when used by itself. In column (5) of Table 1 use the summary measure of benefit entitlements over 1979-1985 given in Table 8.2 of OECD (1994). It is basically the benefits entitlement before tax as a percentage of previous earnings before tax averaged over various earning levels and years of the unemployment benefit (see OECD (1994) for more details). We have some confidence in our instrumental estimates as while it is difficult to get precisely estimated coefficients in the first stage because of so many interactions, reassuringly at least some of the coefficients are consistent with our priors. For example, English speaking countries with high past inflation are more likely to be targeters and countries with histories of high unemployment benefits are less likely to be targeters. 
sample at 1999 when arguably the institutional arrangements of many countries become less clear because of the beginning of the European Monetary Union.

Both the IV and OLS results (Table 1) suggest that targeting in almost all specifications has an insignificant effect on inflation. Moreover the coefficient on the targeting variable is of roughly the same order of magnitude as Ball and Sheridan's estimates and is about one-third the size of Wu's. ${ }^{9}$ We know that these cross-sectional results do have reliable standard errors so prima facia these results confirm Ball and Sheridan's findings that inflation targeting has a small and insignificant effect and at best Wu's results are different because of the increased number of observations available from using quarterly data. To the extent that the goal of inflation targeting is primarily about reducing the medium term inflation rate then Ball and Sheridan's finding disturbingly suggests that the effect is small (even if Wu's estimation procedure is robust). Given the similarity of the the IV and OLS results we can also conclude that while there may be some endogeneity bias, it is not large.

\section{[Insert Table 1 around here]}

Using the cross-sectional data we can also identify the treatment coefficient by examining the estimated covariance matrix of the reduced form equations (see the discussion above). Using inflation after 1995 as the measure of inflation during the treatment period, we find beta is roughly 0.03 which is positive but very small and insignificant (see Table 2). This

9 The only regression to result in a significant and somewhat more substantial estimate for the targeting coefficient is in the 11th column of Table 1. We are skeptical about the weight to put on this result because the result is not robust. 
seems consistent with the result of our findings - that the coefficient is close to zero and insignificant. Moreover some of the other parameter point estimates are consistent with what we expect. Higher inflation is associated with greater inflation in the future and higher past inflation is associated with being a targeter. The scale factor, A, is different from one though it is imprecisely estimated.

[Insert Table 2 around here]

As already discussed, Wu's original paper (2004a) used difference in difference estimation to estimate the effect of targeting which can lead to misleading standard errors. In a revised version of Wu's paper (2004b), he recognizes the problems of using differences in differences estimators and uses Arellano-Bond panel estimation. His specifications include a time trend and one lag. He tests and finds no serial correlation at the 5 percent significance level arguing that this suggests his estimates are reliable. While we find a treatment effect of similar magnitude when using one lag for inflation (see Table 3), we find that higher order lags are significant. Our preferred specification has 12 lags of inflation (for the model without time fixed effects the $12^{\text {th }}$ lag is significant and the 4 and 8 lag models show signs of serial correlation). This suggests his results are likely to be affected by omitted variable bias. For our preferred model, the effect of the target variable is much smaller and insignificant.

[Insert Table 3 around here.] 
Two potential concerns with the above results are that (a) the instruments used in the Arellano-Bond estimation may be weak and (b) the inclusion of 12 lags may be excessive, leading to inefficient estimates. Simple regressions of the first difference of inflation on its lag are highly significant (with $\mathrm{t}$ statistics of around 16 whether or not time fixed effects are included) suggesting that the instruments are not weak. Also we find that the target variable is insignificant and of a similar order of magnitude once we include four lags, suggesting that our results are not being driven by overspecification of the model.

We also present some estimates of the treatment parameter, using Wu's quarterly data and one of the procedures suggested in Bertrand et al. (2002) - the placebo approach (which is based on the randomization inference tests used in statistics). One issue with their placebo approach is that it is not clear exactly what the data generating process of becoming an inflation targeter is. We consider three arguably plausible processes. The first placebo, perhaps the least plausible, is based on the assumption that all countries became inflation targeters but they did so randomly within the sample. This is problematic as not all countries became targeters and no country began targeting early in the sample. The second placebo still assumes that the timing of becoming a targeter is random in the sample but only allows the countries we observe to be inflation targeters to make that transition. This perhaps is also problematic as it allows positive probability that they became targeters in the 1980s. The third placebo captures this concern by allowing the random transition to inflation targeting to only have occurred amongst countries we have seen became inflation targeters and only to occur during the 1990s. 
Table 4 presents our results. Each column represents the results of a different specification (with varying fixed effects and lags of inflation). The first row reports the point estimate and robust standard errors, which we have argued could be misleading. The next three rows report whether based on our three placebo distributions (which are generated under the null that there is no effect) the point coefficient is significant at the 5 per cent level. The results show that the point estimates are large - some even larger than Wu's estimates - and significance is sensitive to the data generating process assumed. However for all three placebos if country and time fixed effects are included with 12 lags, the targeting variable is insignificant. Also the results for the more plausible placebos lead us to conclude these coefficients are insignificant across all specifications.

While the results from the first placebo could be interpreted as providing some evidence that inflation targeting matters, we have a more cautious view. The difference between placebos one and two are the set of countries that are allowed to become inflation targeters. Hence the significant results are likely to be spurious if countries self-select into inflation targetering. We have already argued that this is the case and the instrumental variable results which seek to correct for this bias indicate that the effect of inflation targeting is insignificant and reasonably small.

While the different identification approaches employed suggest somewhat different estimates of the impact of inflation targeting on inflation, they are generally insignificant and suggest that inflation targeting reduces quarterly inflation by around 0.1 percentage 
points. This suggests that it reduces four-quarter ended inflation by on average about 0.4 percentage points which by a number of possible metrics is small. First, inflation targeters typically have a band of one percentage point or more (e.g. Australia and New Zealand). Also, central banks have a fairly imprecise control over inflation. Finally, 0.4 percentage points is small compared to the large drops in inflation seen in many of these countries over the sample period (e.g. inflation in New Zealand fell from around 9 per cent in 1989 to around 2 percent in 1992). Even based on the types of estimates that $\mathrm{Wu}$ obtained, this only explains a small fraction of the observed decrease in inflation.

[Insert Table 4 around here]

\section{Conclusions}

We find that, whatever estimation approach is adopted, the estimated effect of inflation targeting on inflation is generally small and insignificant. Long-run inflation is the ultimate target of inflation targeting central banks and so the cross-section approach of Ball and Sheridan is most relevant. Using this approach, we find similar results whether or not we account for potential endogeneity. While we are able to confirm Wu's results, there are reasons to question their reliability (as he excludes statistically significant lags of inflation). Using more lags of inflation lead to a much smaller estimated effect and, even using his lag specification, alternative ways of calculating the standard errors suggest the coefficient is insignificant. Other identification approaches also generally confirm these conclusions. ${ }^{10}$

10 Some of the other existing literature (e.g. Levin et al (2004) and Truman (2003)) also argues that inflation targeting reduced inflation in developed countries. Truman's results however seem likely to be 
So, at best there is only weak evidence that inflation targeting contributed to the reduction in inflation experienced in developed countries in the 1990s. Nevertheless inflation targeting may have had some benefits. To the extent that the existence of inflation targeting caused an increase in the focus on the costs of inflation during the 1990s and the need to reduce these costs, inflation targeting may have played a role in the global decrease in inflation during the past decade.

due to the exclusion of lagged inflation from their specification which our analysis suggests is significant. Levin et al argue that inflation is less persistent and inflation expectations are lower in inflation targeting countries. While these are interesting and important results, it is not necessarily clear that they demonstrate that inflation targeting has reduced inflation. Papers including developing economies (e.g. IMF, 2005, and Petursson, 2004) provide more convincing evidence that inflation targeting matters (though they do not use IV techniques to control for potential endogeneity). This suggests that inflation targeting may be a useful monetary policy strategy for some countries. 


\section{Data Appendix}

We use Wu's data which is from Q1 1985 to Q3 2002 for the traditional OECD country members: Australia, Austria, Belgium, Canada, Denmark, Finland, France, Germany, Greece, Ireland, Italy, Japan, Luxembourg, Netherlands, New Zealand, Norway, Portugal, Spain, Sweden, Switzerland, the United Kingdom and the United States. They are quarterly inflation rates and the following are considered inflation targeters: Australia (from September 1994), Canada (from February 1991), Finland (from Febuary 1993 to December 1998), New Zealand (from March 1990), Spain (from September 1994 to December 1998), Sweden (from January 1993), Switzerland (from January 2000) and the United Kingdom (from October 1992). For some countries (like Australia) the dating of inflation targeting is not straight forward. (Bernanke et al, 1999, notes the informality with which the Australian inflation target was announced.) Here we adopted the dating of $\mathrm{Wu}$. We do not have benefits data on Luxembourg so it is omitted from the relevant regressions. 


\section{References}

Andersen, P. and D. Gruen,1995, Macroeconomic policies and growth in: Productivity and growth (Reserve Bank of Australia, Sydney).

Arellano, M. and S. Bond, 1991, Some tests of specification for panel data: monte carlo evidence and an application to employment equations, Review of Economic Studies 58, 277-297.

Ball, L. and N. Sheridan, 2003, Does inflation targeting matter? (NBER Working Paper 9577).

Bernanke, B., T. Laubach, F. Mishkin and A. Posen, 1999, Inflation targeting (Princeton University Press, Princeton).

Bertrand, M. , E. Duflo and S. Mullianathan, 2002, How much should we trust difference in difference estimators? (NBER Working Paper 8841).

Boschen, J. and C. Weise, 2004, Does the dynamic time consistency model of inflation explain cross-country differences in inflation dynamics? Journal of International Money and Finance 23, 735-759.

Cukierman, A., S. Webb and B. Neyapti, 1992, Measuring the independence of central banks and its effect on policy outcomes, World Bank Economic Review 6,353-398.

Di Tella, R. and R. MacCulloch, 2001, The welfare state as a substitute for a conservative central banker (Harvard Business School Working Paper No 00-094).

Gertler, M., 2005, Comments on Ball and Sheridan, in: Bernanke and Woodford eds., The inflation targeting debate (NBER). 
Heckman, J. and S. Navarro-Lozano, 2004, Using matching, instrumental variables and control functions to estimate economic choice models, Review of Economics and Statistics 86, 30-57.

Hyvonen, M., 2004 Inflation convergence across countries (Reserve Bank of Australia Discussion Paper 2004-04).

International Monetary Fund, 2005, Does inflation targeting work in emerging markets? in: International Monetary Fund, World Economic Outlook September 2005 (IMF). Levin, A., F. Natalucci and J. Piger, 2004, The macroeconomic effects of inflation targeting, Federal Reserve Bank of St Louis Review 86, 51-80.

Organization for Economic Co-operation and Development, 1994, The OECD jobs study: evidence and explanations part II the adjustment potential of the labour market (OECD, Paris).

Petursson, T., 2004, The effects of inflation targeting on macroeconomic performance (Central Bank of Iceland Working Paper 23).

Rigobon, R., 2003, Identification through heteroskedasticity, Review of Economics and Statistics 85, 777-792.

Truman, E., 2003, Inflation targeting in the world economy (Institute for International Economics).

Vega, M. and D. Winkelried, 2005, Inflation targeting and inflation behavior: A Successful Story? Journal of International Central Banking 1, 153-175. Wu, T., 2004a, Does inflation targeting reduce inflation? An analysis for the OECD industrial countries (Banco Central do Brazil Working Paper 83). 
Wu, T., 2004b, Does inflation targeting reduce inflation? An analysis for the OECD industrial countries, mimeo, Princeton University. 
Table 1: Cross-sectional Results

\begin{tabular}{|c|c|c|c|c|c|c|c|c|c|c|c|}
\hline Model & $\begin{array}{l}\text { OLS } \\
\text { (1) }\end{array}$ & $\begin{array}{c}\text { OLS } \\
(2)\end{array}$ & $\begin{array}{l}\text { IV - } 1^{\text {st }} \\
\text { stage } \\
(3)\end{array}$ & $\begin{array}{l}\mathrm{IV}-1^{\text {st }} \\
\text { stage } \\
(4)\end{array}$ & $\begin{array}{l}\mathrm{IV}-1^{\text {st }} \\
\text { stage } \\
(5)\end{array}$ & $\begin{array}{l}\text { IV }-2^{\text {nd }} \\
\text { stage } \\
(6)\end{array}$ & $\begin{array}{l}\text { IV }-2^{\text {nd }} \\
\text { stage } \\
(7)\end{array}$ & $\begin{array}{l}\text { IV }-2^{\text {nd }} \\
\text { stage } \\
(8)\end{array}$ & $\begin{array}{l}\text { IV }-2^{\text {nd }} \\
\text { stage } \\
(9)\end{array}$ & $\begin{array}{l}\text { IV }-2^{\text {nd }} \\
\text { stage } \\
(10)\end{array}$ & $\begin{array}{l}\text { IV }-2^{\text {nd }} \\
\text { stage } \\
(11)\end{array}$ \\
\hline Dependent Variable & $\begin{array}{l}\text { Change in } \\
\text { Inflation }\end{array}$ & $\begin{array}{l}\text { Change in } \\
\text { Inflation } \\
\text { (up to } \\
\text { 1999) }\end{array}$ & Targeter & Targeter & Targeter & $\begin{array}{l}\text { Change in } \\
\text { Inflation }\end{array}$ & $\begin{array}{l}\text { Change in } \\
\text { Inflation } \\
\text { (up to } \\
\text { 1999) }\end{array}$ & $\begin{array}{l}\text { Change in } \\
\text { Inflation }\end{array}$ & $\begin{array}{l}\text { Change in } \\
\text { Inflation } \\
\text { (up to } \\
1999 \text { ) }\end{array}$ & $\begin{array}{l}\text { Change in } \\
\text { Inflation }\end{array}$ & $\begin{array}{c}\text { Change in } \\
\text { Inflation } \\
\text { (up to } \\
\text { 1999) }\end{array}$ \\
\hline Targeter & $\begin{array}{l}-0.10 \\
(0.07) \\
\end{array}$ & $\begin{array}{l}-0.19 \\
(0.11) \\
\end{array}$ & & & & $\begin{array}{l}-0.10 \\
(0.14) \\
\end{array}$ & $\begin{array}{l}-0.21 \\
(0.20) \\
\end{array}$ & $\begin{array}{l}-0.07 \\
(0.10) \\
\end{array}$ & $\begin{array}{l}-0.18 \\
(0.18) \\
\end{array}$ & $\begin{array}{l}-0.23 \\
(0.12) \\
\end{array}$ & $\begin{array}{l}-0.41^{*} \\
(0.15) \\
\end{array}$ \\
\hline Inflation lagged & $\begin{array}{l}-0.82 * \\
(0.03)\end{array}$ & $\begin{array}{l}-0.74 * \\
(0.06)\end{array}$ & & & & $\begin{array}{l}-0.82 * \\
(0.03)\end{array}$ & $\begin{array}{l}-0.74 * \\
(0.06)\end{array}$ & $\begin{array}{l}-0.83^{*} \\
(0.04)\end{array}$ & $\begin{array}{l}-0.75^{*} \\
(0.06)\end{array}$ & $\begin{array}{l}-0.81 * \\
(0.03)\end{array}$ & $\begin{array}{l}-0.72 * \\
(0.05)\end{array}$ \\
\hline English speaking & & & $\begin{array}{c}0.14 \\
(0.55) \#\end{array}$ & $\begin{array}{l}3.02 * \\
(0.89) \#\end{array}$ & & & & & & & \\
\hline $\begin{array}{l}\text { English speaking } \times \\
\text { Past inflation }\end{array}$ & & & $\begin{array}{c}0.29 \\
(0.26) \#\end{array}$ & $\begin{array}{l}-1.64 * \\
(0.68) \#\end{array}$ & & & & & & & \\
\hline Cukerierman & & & & $\begin{array}{c}0.32 \\
(0.44) \#\end{array}$ & & & & & & & \\
\hline $\begin{array}{l}\text { Cukierman } \times \\
\text { Past Inflation }\end{array}$ & & & & $\begin{array}{l}-1.10 \\
(0.81) \#\end{array}$ & & & & & & & \\
\hline $\begin{array}{l}\text { Cukierman } \times \\
\text { English speaking }\end{array}$ & & & & $\begin{array}{l}-7.29 * \\
(3.21) \#\end{array}$ & & & & & & & \\
\hline $\begin{array}{l}\text { Cukierman } \times \\
\text { English speaking } \times \\
\text { Past inflation }\end{array}$ & & & & $\begin{array}{l}5.10^{*} \\
(2.20) \#\end{array}$ & & & & & & & \\
\hline Benefits & & & & & $\begin{array}{c}-0.02 \\
(0.01) \#\end{array}$ & & & & & & \\
\hline $\begin{array}{l}\text { Benefits } \times \\
\text { Past Inflation }\end{array}$ & & & & & $\begin{array}{l}0.03^{*} \\
(0.01) \#\end{array}$ & & & & & & \\
\hline Past Inflation & & & $\begin{array}{c}0.04 \\
(0.08) \\
\end{array}$ & $\begin{array}{c}0.58 \\
(0.43) \\
\end{array}$ & $\begin{array}{l}-0.21 * \\
(0.07) \\
\end{array}$ & & & & & & \\
\hline F test for \# variables & & & $\begin{array}{l}9.15^{*} \\
{[0.00]}\end{array}$ & $\begin{array}{l}30.88^{*} \\
{[0.00]}\end{array}$ & $\begin{array}{l}9.88^{*} \\
{[0.00]}\end{array}$ & & & & & & \\
\hline $\begin{array}{l}\text { Instrument from } \\
\text { Model }\end{array}$ & & & & & & (3) & (3) & (4) & (4) & (5) & (5) \\
\hline
\end{tabular}

Robust standard errors in parenthesis and $p$ values in brackets. * Significant at the 5 percent level.

The dependent variable is (a) whether or not the central bank became a targeter, (b) change in inflation from pre-1990 to post-1994 or (c) change in inflation from pre-1990 to $1995-1998$. 
Table 2: Model Estimates Based on Heteroscedasticity Assumption

\begin{tabular}{|c|c|c|c|c|c|c|c|c|}
\hline$\beta$ & $\sigma_{\varepsilon}{ }^{2}$ & $\sigma_{\mathrm{u}}{ }^{2}$ & $\sigma_{\mathrm{u} \varepsilon}$ & $\mathrm{A}$ & $\delta$ & $\rho$ & $\alpha$ & $\psi$ \\
\hline $\begin{array}{c}\text { Effect of } \\
\text { targeting } \\
\text { on } \\
\text { inflation }\end{array}$ & $\begin{array}{c}\text { Variance } \\
\text { for } \\
\text { inflation }\end{array}$ & $\begin{array}{c}\text { Variance } \\
\text { for } \\
\text { targeting }\end{array}$ & Covariance & $\begin{array}{c}\text { Scale } \\
\text { factor } \\
\text { for high } \\
\text { inflation }\end{array}$ & $\begin{array}{c}\text { Constant } \\
\text { term for } \\
\text { targeting }\end{array}$ & $\begin{array}{c}\text { Effect of } \\
\text { past } \\
\text { inflation } \\
\text { on target }\end{array}$ & $\begin{array}{c}\text { Constant } \\
\text { term for } \\
\text { inflation }\end{array}$ & $\begin{array}{c}\text { Effect of } \\
\text { past } \\
\text { inflation } \\
\text { on } \\
\text { inflation }\end{array}$ \\
\hline $\begin{array}{c}0.03 \\
(0.1)\end{array}$ & 0.04 & 0.18 & -0.02 & $\begin{array}{c}0.69 \\
(-1.4)^{*}\end{array}$ & $\begin{array}{c}-0.005 \\
(-0.03)\end{array}$ & $\begin{array}{c}0.24 \\
(2.0)\end{array}$ & $\begin{array}{c}0.34 \\
(4.8)\end{array}$ & 0.15 \\
$(2.4)$
\end{tabular}

Point estimates and t-statistics are reported in parentheses. Estimated by efficient GMM. ${ }^{*}$ This is a $t$ statistic for A being less than one. 
Table 3: Panel Regressions of Inflation

\begin{tabular}{|l|c|c|c|c|c|c|}
\hline Target & $\begin{array}{c}-0.36^{*} \\
(0.13)\end{array}$ & $\begin{array}{c}-0.36^{*} \\
(0.13)\end{array}$ & $\begin{array}{c}-0.35^{*} \\
(0.16)\end{array}$ & $\begin{array}{c}-0.10 \\
(0.08)\end{array}$ & $\begin{array}{c}-0.10 \\
(0.08)\end{array}$ & $\begin{array}{c}-0.005 \\
(0.08)\end{array}$ \\
\hline Inflation lags & 1 & 1 & 1 & 12 & 12 & 12 \\
\hline Country effects & Yes & Yes & Yes & Yes & Yes & Yes \\
\hline Time effects & No & No & Yes & No & No & Yes \\
\hline Time trend & No & Yes & No & No & Yes & No \\
\hline $\begin{array}{l}\text { Autocorrelation } \\
\text { Test p value }\end{array}$ & 0.15 & 0.15 & 0.12 & 0.16 & 0.16 & 0.11 \\
\hline
\end{tabular}

Arellano-Bond estimation assuming the targeting variable is exogenous. The Sargan $p$ value for all regressions is 1 . The autocorrelation test is a test of whether the average autocovariance of residuals of order 2 is zero. Robust standard errors in parenthesis and p values in brackets. ${ }^{*}$ Significant at the 5 percent level. 
Table 4: Placebo Panel Regressions of Inflation

\begin{tabular}{|l|c|c|c|c|c|c|}
\hline Target & $\begin{array}{c}-0.87 \\
(0.08)\end{array}$ & $\begin{array}{c}-0.69 \\
(0.08)\end{array}$ & $\begin{array}{c}-0.15 \\
(0.07)\end{array}$ & $\begin{array}{c}-0.40 \\
(0.09)\end{array}$ & $\begin{array}{c}-0.35 \\
(0.08)\end{array}$ & $\begin{array}{c}-0.02 \\
(0.07)\end{array}$ \\
\hline $\begin{array}{l}\text { Significant } \\
\text { Placebo 1 }\end{array}$ & Yes & Yes & No & Yes & Yes & No \\
\hline $\begin{array}{l}\text { Significant } \\
\text { Placebo 2 }\end{array}$ & No & No & No & No & No & No \\
\hline $\begin{array}{l}\text { Significant } \\
\text { Placebo 3 }\end{array}$ & No & No & No & No & No & No \\
\hline $\begin{array}{l}\text { Inflation } \\
\text { lags }\end{array}$ & None & 1 & 12 & None & 1 & 12 \\
\hline $\begin{array}{l}\text { Country } \\
\text { effects }\end{array}$ & Yes & Yes & Yes & Yes & Yes & Yes \\
\hline Time effects & No & No & No & Yes & Yes & Yes \\
\hline
\end{tabular}

All regressions are regressions of quarterly inflation with country and time fixed effects. Significance statements are based on the two tailed test at the 5 per cent level.

Placebo 1 assumes random transition of all countries to inflation targeting some time in the sample.

Placebo 2 assumes random transition of inflation targeting countries some time in the sample.

Placebo 3 assumes transition of the inflation targeting countries in the 1990s. 